\title{
MESIAL TEMPORAL SCLEROSIS IN CHILDREN
}

\author{
Eliana Maria Domingues Brandão', Maria Luiza Giraldes de Manreza²
}

\begin{abstract}
Mesial temporal sclerosis is the most frequent cause of drug-resistant temporal lobe epilepsy but has a satisfactory response to surgery, and is considered infrequent in children. Objective: To evaluate the clinical, electrographic and radiological spectrum of the disease in children. Method: Retrospective study by review of charts of 44 children with a diagnosis of mesial temporal sclerosis on magnetic resonance imaging, attended at the "Hospital das Clínicas" of the University of São Paulo Faculty of Medicine. Results: Febrile seizure was identified in the history of $54 \%$ of the patients. Injuries at the left side predominated in patients with schooling difficulties $(p=0.049)$, in those with the first seizures between six months and five years $(p=0.021)$ and in those with complex febrile seizure $(p=0.032)$. Thirteen patients were submitted to surgery and of these, eight remained without seizures. Conclusion: Febrile seizure may be related in a more direct way to the presence of left-side mesial temporal sclerosis.
\end{abstract}

KEY WORDS: temporal lobe epilepsy, child, adolescent, sclerosis, hippocampus.

\begin{abstract}
Esclerose mesial temporal em crianças
RESUMO - Em adultos, esclerose mesial temporal é a causa mais freqüente de epilepsia do lobo temporal intratável por medicamentos e que responde satisfatoriamente a cirurgia, sendo considerada pouco freqüente em criança. Objetivo: Avaliar o espectro clínico, eletrográfico e radiológico desta patologia em crianças. Método: Estudo retrospectivo, por revisão de prontuário de 44 crianças com diagnóstico de esclerose mesial temporal na ressonância magnética, atendidos no Hospital das Clínicas da Faculdade de Medicina de São Paulo. Resultado: Foi identificado que $54 \%$ dos pacientes apresentaram antecedente de crise febril. Lesão no lado esquerdo predominou nos pacientes com dificuldade escolar $(p=0.049)$, naqueles com primeiras crises entre seis meses e cinco anos $(p=0,021)$ e naqueles com crise febril complicada $(p=0,032)$. Treze pacientes foram operados, dos quais oito ficaram livres de crises. Conclusão: Crise febril pode estar relacionada de uma forma mais direta à presença de esclerose mesial temporal no lado esquerdo.
\end{abstract}

PALAVRAS-CHAVE: epilepsia do lobo temporal, criança, adolescente, esclerose, hipocampo.

Epileptic seizures of the temporal lobe constitute the most frequent presentation of drug-resistant epilepsy which satisfactorily responds to surgical treatment ${ }^{1}$. The most commonly found injury in adults is mesial temporal sclerosis (MTS) ${ }^{2,3}$.

In children with temporal lobe epilepsy, MTS is considered an infrequent etiology 4,5 , but with the advances in neuroimaging, MTS which was thought to be a disease of adults, started to be diagnosed at an increasingly younger age $\mathrm{e}^{6-9}$.

The aim of this study was to evaluate the clinical, electrographic and radiologic MTS spectrum in children and establishing the differences as compared to manifestations observed in adults.

\section{METHOD}

This is a retrospective study by reviewing data of charts of 44 pediatric patients with a MTS diagnosis on magnet- ic resonance imaging (MRI), attended at the "Hospital das Clínicas" of the University of São Paulo Medical School in the period from January 1997 to December 2001. This study was approved by the Ethics Committee for the Analysis of Research Projects of the "Hospital das Clínicas" on 04.24.03. Patients' age was $\leq 18$ years at radiologic diagnosis and they were analyzed regarding clinical symptoms, personal histories of febrile seizure, interictal electroencephalogram data, neuroimaging data and post-surgical progress of operated patients.

\section{RESULTS}

Forty-four charts were reviewed of patients who were $\leq 18$ years old on occasion of the radiologic MTS diagnosis established at the "Hospital das Clínicas". All patients presented epilepsy. There was no predominance regarding gender $(22 \mathrm{M} / 22 \mathrm{~F}) ; 83.7 \%$ of the patients presented their first seizure (febrile or non febrile) up to the age of five years.

Divisão de Neurologia do Hospital das Clínicas da Faculdade de Medicina da Universidade de São Paulo, São Paulo SP, Brazil (HC/ FMUSP): 'Médica Plantonista; ${ }^{2}$ Médica Assistente Chefe do Ambulatório de Epilepsia Infantil.

Received 19 October 2006, received in final form 8 June 2007. Accepted 7 August 2007.

Dra. Eliana Maria Domingues Brandão - Rua Vicente Oropallo 61 / apto 61 - 05351-025 São Paulo SP - Brasil. E-mail: sermaju@uol.com.br 
Table 1. Clinic semiology according to focal seizures start age.

\begin{tabular}{|c|c|c|c|c|c|}
\hline \multirow[t]{2}{*}{ Phenomena } & \multicolumn{2}{|c|}{$<5$ years } & \multicolumn{2}{|c|}{$>5$ years } & \multirow{2}{*}{$\begin{array}{l}\text { Exact test } \\
\text { Fisher }(p)\end{array}$} \\
\hline & yes & no & yes & no & \\
\hline Motor & 20 & 5 & 11 & 4 & 0.750 \\
\hline Tonic motor & 13 & 12 & 6 & 9 & 0.527 \\
\hline Versive & 6 & 19 & 5 & 10 & 0.491 \\
\hline Hypokinetic & 13 & 12 & 11 & 4 & 0.114 \\
\hline Dyscognitive & 5 & 20 & 6 & 9 & 0.272 \\
\hline Epigastric & 7 & 18 & 8 & 7 & 0.108 \\
\hline Oroalimentary automatism & 12 & 13 & 7 & 8 & 0.999 \\
\hline Gestural automatism & 4 & 21 & 7 & 8 & 0.015 \\
\hline Autonomic & 8 & 17 & 5 & 10 & 0.999 \\
\hline
\end{tabular}

Table 2. Data distribution as to lesion side and schooling difficulty.

\begin{tabular}{lccc}
\hline MR/ side & \multicolumn{2}{c}{ School difficulty } & Total \\
\cline { 2 - 3 } & No & Yes & \\
\hline Right temporal & 15 & 1 & 16 \\
Left temporal & 12 & 7 & 19 \\
Bilateral temporal & 4 & 3 & 7 \\
Total & 31 & 11 & $42^{*}$ \\
\hline
\end{tabular}

*Total patients with recording about schooling difficulty in the charts.

Focal seizures started before the age of five in $62.5 \%$ of the cases and in $39 \%$ there was no seizurefree interval.

Regarding personal histories, 21 of 39 patients (54\%) presented a history of febrile seizures, of which $11(52 \%)$ were complex febrile seizures; status epilepticus occurred in 12 patients.

Focal seizure semiology was classified according to the glossary of descriptive terminology for ictal semiology of the International League Against Epilepsy $2001^{10}$. The results obtained in 40 patients with the respective result of Fisher exact test are shown in Table 1.

All patients presented alteration on MRI. In 27 cases (61.4\%) there was increased signal in $\mathrm{T}_{2}$ of the hippocampus and in 23 cases (52.3\%) hippocampal volume loss. In 20 cases $(45 \%)$ there are reports of both increased signal in T2 and volume loss in unilateral hippocampus. In 14 cases (32\%) description reported only MTS. There is no report on other hippocampal alterations in descriptions of the examinations. Regarding laterality, in 20 cases ( $45 \%$ ) MTS occurred at the left, in 16 cases at the right side and in eight cases it was bilateral.

An association study was performed, using again Fisher exact test, between the side of injury and schooling difficulty with predominance of schooling difficulty among the patients with right-side injury $(p=0.049)$, as shown in Table 2.

Table 3 shows the age at onset of the seizures, either febrile or non febrile. Association between left-side injury and seizures beginning between six months and five years of age, showed the highest statistical significance $(p=0.021)$.

A statistically significant association between complex febrile seizure and left-side injury was obtained $(p=0.032)$ as shown in Table 4.

Study of the association between control of seizures and: 1$)$ age at the first seizure $(p=0.999), 2)$ age at the first focal seizure $(p=0.715), 3$ ) complex febrile seizure $(p=0.740)$ was also performed. No significant association between these factors occurred.

One to six electroencephalograms were obtained from each patient, at a total of 106 examinations of

Table 3. Data distribution as to side lesion and first seizure age.

\begin{tabular}{|c|c|c|c|c|c|c|c|}
\hline \multirow[t]{2}{*}{$\mathrm{MR} /$ side } & \multicolumn{6}{|c|}{ First seizure age } & \multirow[t]{2}{*}{ Total } \\
\hline & $<6$ month & $\begin{array}{l}>6 \text { month } \\
\text { until } 1 \text { year }\end{array}$ & $\begin{array}{l}>1 \text { until } \\
2 \text { year }\end{array}$ & $\begin{array}{c}>2 \text { until } \\
5 \text { year }\end{array}$ & $\begin{array}{l}>5 \text { until } \\
10 \text { year }\end{array}$ & $>10$ years & \\
\hline Right temporal & 5 & 1 & 1 & 4 & 4 & 1 & 16 \\
\hline Left temporal & o & 7 & 4 & 7 & 1 & o & 19 \\
\hline Bilateral temporal & o & 4 & 1 & 2 & 1 & o & 8 \\
\hline Total & 5 & 12 & 6 & 13 & 6 & 1 & $43^{*}$ \\
\hline
\end{tabular}

*Total of patients with this data in the chart. 
Table 4. Data distribution as to side lesion and complex febrile seizure.

\begin{tabular}{lcccc}
\hline MR/side & \multicolumn{3}{c}{ Complex febrile seizure } & \multirow{2}{*}{ Total } \\
\cline { 2 - 4 } & No & Yes & $\begin{array}{c}\text { Without febrile } \\
\text { seizure antecedent }\end{array}$ & \\
\hline Righ temporal & 1 & 1 & 11 & 13 \\
Left temporal & 2 & 6 & 5 & 13 \\
Bilateral temporal & 0 & 4 & 2 & 6 \\
Total & 3 & 11 & 18 & $32^{*}$ \\
\hline
\end{tabular}

*Total of patients that had these data clear in the chart.

which $45(42 \%)$ presented alteration in the temporal region.

Thirteen patients underwent surgery, of whom eight became seizure-free, two rarely had seizures, two present no improvement and in one patient follow-up was lost four months after surgery. Fisher exact test was used to compare operated and non-operated patients regarding the number of used antiepileptic drugs (AED) and control of seizures. There was no association with seizure control $(p=0.999)$ and a tendency was found regarding the number of AED ( $p=0.111)$.

\section{DISCUSSION}

Among the analyzed patients there was predominance in any age range regarding age at the first seizure, but $53.5 \%$ of the children presented their first seizure up to the age of 2 years and $83.7 \%$ up to the age of five, in agreement with the studies on mesial temporal lobe epilepsy in adults ${ }^{7,11,12}$, and in children ${ }^{13,14}$.

There was no silent interval in $39 \%$ of the children who started symptomatology with temporal focal seizures and in other $22 \%$ the interval was less than one year, which may suggest that in many patients MTS could be the factor responsible for the first seizures and not their consequence as has been pointed out in the past ${ }^{2,15}$.

Statistically, febrile seizure is the most strongly related to mesial temporal sclerosis symptomatology ${ }^{12,14,16-18}$. For Saltik et al. ${ }^{19}$, the febrile seizure is associated with MTS mainly when seizures start early or are present as complex febrile seizures or even as status febrile.

Studies using quantitative MRI reveal that patients with prolonged febrile seizure history present more pronounced atrophy of the amygdala and hippocampal formation ${ }^{20,21}$, and a more prolonged relaxation time in T2 as compared to patients with MTS without history of febrile seizure ${ }^{22}$. RMI study of patients with temporal epilepsy performed by Kodama et al. ${ }^{23}$ is also in agreement with a higher incidence of prolonged febrile seizure and MTS.
Literature on MTS in children ${ }^{9,11}$ points to oroalimentary automatism, gestural automatism, decreased responsiveness and motor phenomenon as the most frequent critical phenomena. Except for gestural automatism, these were also the most frequently identified phenomena in the present study. These manifestations are also common in adults with mesial temporal lobe epilepsy ${ }^{24}$. Epigastric phenomenon and fear, although being frequent manifestations in adults ${ }^{12,25}$, present lower incidence among children, maybe due to the difficulty of the child to report these sensations. In the statistical analysis of this study, seizure semiology did not present a significant difference between the evaluated groups and the only data where a difference regarding age occurred, was gestural automatism, with predominance in children older than five years. This data agrees with studies on semiology of epileptic seizures stratified by age range groups where adolescents presented more pronounced automatism when compared to schooland preschool children ${ }^{9,26.27}$.

Particularities of focal seizures in small children may be related more to age, and consequently to central nervous system maturity, than to specific localization $^{28}$ and probably there is immaturity of the inhibitory system of the central nervous system in younger children. ${ }^{26}$

Association between schooling difficulty and leftside injury was found. Experimental studies point to the hippocampus as an important structure in the explicit memory process (for autobiographic events and knowledge about facts ${ }^{29,30}$ ) and temporary information storage of long-term memory, but there is no quantification of the participation of each side and more alterations of memory being evident when bilateral injury occurs.

Regarding age at first seizure (febrile or non febrile), it was observed that in children with left-side injury it occurred between the age of sixth months and five years, a period coinciding with age range 
of febrile seizures while those who presented first seizure before the age of six months had MTS signs on the right on MRI. Regarding febrile seizure, it was observed that the children with a prolonged seizure tended to present injury predominantly in the left hippocampus or bilaterally, while in those without febrile seizure, it was on the left side. In the study by Janszky et al..$^{31}$ the patients with right-side injury presented a higher percentage of febrile seizures in their history when compared to patients with left-side injury. This data disagrees with that found in the present study, but there are no studies in the literature which explain predominance of side regarding febrile seizure, constituting one more point to be added to the many still obscure points regarding MTS. No association was obtained between MTS side and cognitive deficiency, delay in speaking or age focal seizure onset. The results in children submitted to surgery are equal to those found in adults ${ }^{4}$. Comparing the group of operated with that of non-operated patients of the present study, there was no statistically significant difference regarding seizure control, but there was difference as concerns the used AED number, since the non-operated children used a higher number of $A E D$, a fact directly related to control of seizures and consequently to the patients' quality of life. On the other hand, there was no correlation between seizure control and any of the following factors: age at first seizure, age at focal seizure onset, complex febrile seizure.

Conclusions of the present study were that all children with a radiologic MTS diagnosis presented a history of epilepsy. Focal epileptic seizures were mainly characterized by stopping to move, motor phenomenon and oroalimentary automatism.

Seizures with gestural automatism are more common in children over five years old. Epigastric phenomenon and fear are less frequent phenomena in children. Febrile seizure history is more related to leftside MTS presence.

Although there are no significant differences regarding progression, children submitted to surgery need a smaller number of AED for the control their seizures, this meaning a better quality of life.

\section{REFERENCES}

1. Dreifuss FE. Goals of surgery for epilepsy. In Engel J Jr (Ed). Surgical treatment of the epilepsies. New York: Raven Press, 1987:31-49.

2. Mathern GW, Babb TL, Armstrong DL. Hippocampal sclerosis. In Engel J.Jr, Pedley TA (Eds.) Epilepsy: a comprehensive textbook. Philadelphia: Lippincott-Raven, 1997:133-155.

3. Magerison JH, Corsellis JAN. Epilepsy and the temporal lobes: a clinical, electroencephalographic and neuropathological study of the brain in epilepsy, with particular reference to the temporal lobes. Brain 1966;98:499-530.
4. Harvey AS, Berkovic SF, Wrennall JA, Hopkins IJ. Temporal lobe epilepsy in childhood: clinical, EEG, and neuroimaging findings and syndrome classification in a cohort with new-onset seizures. Neurology 1997;49:960-968.

5. Wyllie E, Comair YG, Kotagal P, et al. Seizure outcome after epilepsy surgery in children and adolescents. Ann Neurol 1998;44:740-748.

6. Willye E, Chee M, Granström ML, et al. Temporal lobe epilepsy in early childhood. Epilepsia 1993;34:859-868.

7. Murakami N, Ohno S, Oka E, Tanaka A. Mesial temporal lobe epilepsy in childhood. Epilepsia 1996;37(Suppl 3):S52-S56.

8. Kanos CC, Keith GD, O'Brien T, Dohan Jr FC. Hippocampal sclerosis in a two-year-old with temporal lobe epilepsy: case report with pathological confirmation. Pediatr Neurosur 2000;32:316-320.

9. Mohamed A, Willye E, Ruggieri P, et al. Temporal lobe epilepsy due to hippocampal sclerosis in pediatric candidates for epilepsy surgery. Neurology 2001;56:1643-1648.

10. Blume WT, Lüders HO, Mizrahi E, Tassinari C, vanEmde Boas W, Engel Jr J. Glosssary of descriptive terminology for ictal semiology: report of the ILAE task force on classification and terminology. Epilepsia 2001; 42:1212-1218.

11. Glaser GH. Natural history of temporal lobe-limbic epilepsy. In Engel J Jr (Ed.) Surgical treatment of the epilepsies. New York: Raven Press 1987:13-30.

12. French JA, Willianson PD, Thadani VM, et al. Characteristics of medial temporal epilepsy. I. Results of history and physical examination. Ann Neurol 1993;34:774-780.

13. Zix C, Billard C, Motte J. L'épilepsie liée à une sclérose mésiotemporale chez l'enfant: dix observations. Arch Pédiatr 1999;6:398-405.

14. Lindsay J, Glaser G, Richards Peronelle, Ounsted C. Developmental aspects of focal epilepsies of childhood treated by neurosurgery. Develop Med Child Neurol 1984;26:574- 587.

15. Cukiert A, Andrioli MS, Caner-Cukiert AR. Arq Neuropsiquiatr 1997;55:646-649.

16. Mayanagi Y, Watanabe E, Kaneko Y. Mesial temporal lobe epilepsy: clinical features and seizures mechanism. Epilepsia 1996;37(Suppl 3):S56-S60.

17. Willianson PD, French JA, Thadani VM, et al. Characteristics of medial temporal lobe epilepsy: II. Interictal and ictal scalp eletrencephalography, neuropsychological testing, neuroimaging surgical results, and pathology. Ann Neurol 1993;34:781-787.

18. Harvey SA, Grattan-Smith JD, Desmond PM, Chow CW, Berkovic SF. Febrile seizures and hippocampal sclerosis: frequent and related findings in intractable temporal lobe epilepsy of childhood. Pediatric Neurol 1995;12:201-206.

19. Saltik S, Angay A, Özkara Ç, Demirbilek V, Dervent A. A retrospective analisys of patients with febrile seizures followed by epilepsy. Seizure 2003;12:211-216.

20. Cendes F, Andermann F, Dubeau F, et al. Early childhood prolonged febrile convulsions, atrophy and sclerosis of mesial structures, and temporal lobe epilepsy: an MRI volumetric study. Neurology 1993;43:10831087.

21. Kurks JBM, Cook MJ, Fish DR, Stevens JM, Shorvon SD. Hippocampal sclerosis in epilepsy and childhood febrile seizures. Lancet 1993; 342:1391-1394.

22. Scott RC, Gadian DG, Cross JH, Wood SJ, Neville BGR, Connelly A. Quantitative magnetic resonance characterization of mesial temporal sclerosis in childhood. Neurology 2001;56:1659-1665.

23. Kodama K, Murakami A, Yamanouchi N. MR in temporal lobe epilepsy: early childhood onset versus later onset. Am J Neuroradiol 1995;16:523-529.

24. Maldonado HM, Delgado-Escueta AV, Walsh GO, Swartz BE, Rand RW. Complex partial seizures of hippocampal and amydalar origin. Epilepsia 1988;29:420-433.

25. Jorge CL. Epilepsia com esclerose mesial temporal: aspectos clínicos e fisiopatológicos (dissertação). São Paulo, 1995.

26. Yamamoto N, Watanabe K, Negoro T, et al. Complex partial seizures in children: ictal manifestations and their relation to clinical course. Neurology 1987;37:1379-1382.

27. Olbrich A, Urak L, Gröppel G, et al. Semiology of temporal lobe epilepsy in children and adolescents value in lateralizing the seizure onset one. Epilepsy Res 2002;48:103-110.

28. Achaya JN, Willye E, Lüders HO, Kotagal P, Lancman M, Coelho M. Seizure symptomatology in infants with localization related epilepsy. Neurology 1997;18:189-196.

29. Kandel ER, Schwartz JH, Jessell TM (Eds). Fundamentos da neurociência e do comportamento. Rio de Janeiro: Guanabara Koogan, 1997.

30. Bear MF, Connors BW, Paradiso MA.Neurociências: desvendando o sistema nervoso. Tradução de Quillfeldt JA. 2.Ed. Porto Alegre: Artmed, 2002.

31. Jansky J, Woermann P, Barsi P, Schultz R, Halász P, Ebner A. Right hippocampal sclerosis is more common than left after febrile seizures. Neurology 2003:60:1209-1210. 